\title{
O URBANO DA LISBOA DE URBANO
}

Marcelo Pacheco Soares ${ }^{1}$

RESUMO: Este artigo empreende uma leitura crítica do conto "Trânsito", de Urbano Tavares Rodrigues.

PALAVRAS-CHAVE: 1. Conto; 2. Cidades; 3. Literatura Portuguesa Contemporânea.

\section{URBANO'S LISBON URBANITY}

ABSTRACT: This article undertakes a critical reading of the short-story "Trânsito" by Urbano Tavares Rodrigues.

KEYWORDS: 1. Tale; 2. Cities; 3. Contemporary Portuguese Literature.

\footnotetext{
${ }^{1}$ Recém Doutor em Literatura Portuguesa pela Faculdade de Letras da UFRJ e Professor do IFRJ.
} 


\section{TRÂNSITO}

Como aquela tapeçaria, de cor indefinida, entre o rosa e o amarelo, deve ser o cetim dos ventres interiores.

Espelhos há quatro. Ou cinco? E quando as bailarinas sorriem — não sei, de resto porque sorriem - tenho nas mãos uma renda de sal; há espumas, e há ondas, e areias sujas e conchas nesta tapeçaria que os espelhos multiplicam e sobre a qual escorre do tecto, da luz, um suor de estrelas.

Uma das bailarinas chora. Vejo as gotas de vidro que lhe descem pela face morena e esguia. São cinco bailarinas brancas, em um divertissement que eu conheço. Que reconheço... Lenta e gravemente, como animais sagrados, dançam entre os prismas e numa folhagem de dedos se elevam, em pontas, presos aos braços os véus que são quase só poeira. Tchaïkovski? Stravinski? Honegger? É a Sinfonia dos Salmos? O Concerto Barroco?... Tudo se pode dançar... E não há cenário, senão a perspectiva infinda dos espelhos. A música mal se ouve, interrompida; é luz decapitada, longe.

Vem na minha direcção, correndo, uma delas. Pirouettes, croisés, développés. A variação da primeira bailarina. A outra, a que chora, com olhos de gazela, assustados, com as pernas muito longas, tem um sorriso súbito pelo meio das lágrimas, um sorriso intenso, pueril, quando a puxo para fora do círculo iluminado e lhe enxugo o rosto com o meu lenço.

- Rosa!

- Não o conheço...

- Como é isso?!

— Ou já o esqueci... Ninguém se conhece, não é verdade?

E continua a chorar. Junta-se ao grupo, deixa-me. Torce os cabelos negros. Tem agora movimentos convulsivos. O bailarino, que está de costas para mim, faz seis fouettés, e depois uma série de jetés, passos de tesoura, arabescos e mais arabescos, não se cansa, salta com as pernas unidas — tem uns músculos formidáveis - e cai sem choque, sem ruído. Todas acodem, de roda dele, nem Willis nem sílfides, apenas rapariguinhas de branco, quase gémeas. Só ela fica parada, em estátua, os olhos na sombra, encovados, o cabelo até a curva dos rins, o peito saliente, o ombro direito num reflexo de bronze, o braço caído. Está de perfil, mas a face voltada para mim. Sentamonos num banco de pedra, encostado à parede, aos espelhos, e envolve-lhe o ombro com o meu braço aflito, pesado não sei se de remorso se de incerteza. Mas a sua pele clareia, o olhar tornou-selhe quase verde, talvez por efeito das lágrimas, embora há pouco fosse negro, bem negro, ou castanho muito escuro; e toda ela se cristalizou numa expressão tristíssima. Sequer um resto de esperança.

- Luísa!

— Não. Não vale a pena. Não te esforces...

Entrego-lhe o meu lenço. Afasto-me. Ela regressa ao círculo luminoso. Tenho na boca um sabor de anéis oxidados. O mais impressionante é que ela se afasta, bailando, com gestos quase burlescos, até que estaca, já ao pé das outras e, sem me ver, sem me pensar, com certeza, o rosto muito erguido, assenta o joelho direito no círculo iluminado.

Terminou a festa, suponho, e a rua está fria. O Inverno veio até nós. Não é de estranhar esta humidade alvacenta, que engole fatias de edifícios e ora esconde, ora revela o anúncio luminoso da Canadian Pacific sobre a calma Avenida da República.

O prof. Benavente caminha a meu lado, ainda mais esgalgado, adunco, irónico e prazenteiro do que há dez anos. Não me surpreende, aliás, tê-lo reencontrado.

— Não, meu amigo — diz ele, e por detrás de cada palavra lenta ouço a água, a água mansa do silêncio nocturno - a tese do sonho nunca pode ser a tese da percepção, mesmo que à primeira vista se lhe pareça. Eu sonho, logo não percebo...

- Como?... Ah! sim... O Sartre...

— O sonho é frágil, desfaz-se ante a consciência reflexiva...

- Curioso!

- Não, é bem simples. Está a ouvir?

Rosa, Luísa ou Júlia, a figura da mulher-criança dói-me no peito ao atravessarmos a Avenida da República. Está frio, sinto nas mãos umas luvas de gelo.

- A diferença entre o sonho e a percepção é a diferença entre a consciência de crer e a consciência de saber.

- Pois é...

Os alambicados prédios Valmor, com seus arcos e azulejos, seus tortos cordões de pedra e suas cornijas, encimadas de conchas e pífias estilizações, colunatas, capitéis chorudos, encaracolados suportes das varandas - balcões e balaustradas gordas, dentes inchados, cúpulas, sótãos escoltados 
de vasos de estuque, e por baixo mascarões e arremedos de feras hiantes — são acariciados, percorridos pela névoa fugidia, que se esgarça, mantilha clara, já rota, aqui e além, e logo pousa nas empenas baixas, descobre pinas, pâmpanos, florões, mansardas de ardósia e junto de nós pórticos, intercolúnios, contrafortes, obesos adornos assimétricos, e os ferros forjados, as cancelas, as grelhas das caves além dos nossos pés, que medem as pedrinhas alvi-negras do passeio. Outro anúncio luminoso: "Beba Fanta".

Damos as costas à praça de touros morisca e vamos direitos à torre branca da igreja de Fátima, cuja cruz intensamente amarela tem também, de cada lado, por cima, rendilhados de mesquita.

Mas, chegados que somos às luzes intermitentes da sinalização, o tempo distanciou-se e quanto mais avançamos menos lhe apercebo os contornos. É, sim, um imenso stand de automóveis — verdes, beges, cinzentos, piscíneos, cromados, alinhados em placa de cristal — o edifício, todo em planos horizontais e com painéis de polyester translúcido, que se ergue na nossa frente.

Mais adiante, são prédios espiroidais, com enormes biombos de ardósia nas janelas e que assentam sobre colunas alvos ladrilhos, transparentes; as portas como tetas egípcios; e nos mosaicos apercebem-se hieróglifos, que afinal não são hieróglifos.

O professor, desatento ao que nos rodeia, fala comigo-consigo:

- Sempre fui um agnóstico, meu caro, sempre considerei, como Epicuro, que se pensa na morte precisamente porque se está vivo. É claro que, mesmo para um materialista, o espírito, com maiúscula, existe, não tenho pudor de o afirmar, e é mesmo essa força motriz, a dos factos morais, a par dos factos económicos, dos factos sociais, que vai transformando o mundo, na sua marcha de internas contradições... Mas onde está a igreja? Não nos teremos perdido? percebo...

- Que ideia! Conheço muito bem o caminho da minha casa. Mas, realmente, não

- Ainda aqui mora?

- Nunca morei noutro sítio.

Não reconheço esta rua por onde os nossos passos ressoam, insólitos, rua de puro som, com ascéticos renques de concreto, ritmos agora verticais, paredes de uma compacta carnação cinzenta, com olhos vazados, janelas que abrem, as mais baixas, sobre cercas desertas. Mas a estas casas quase angustiantes, de que não tenho memória (tão depressa a cidade se transforma... e a noite tudo confunde) sucedem-se altas construções de vidros e de aço, luminosas e que, no entanto, não me desoprimem (tão-pouco consigo recordá-las, orientar-me), múltiplas gaiolas geométricas, inquietantemente serenas e vazias, como ideias sem matéria. No interior, à nossa vista, veem-se filas de secretárias desabitadas, ventoinhas imóveis, escadas rolantes que pararam. Apenas em constante movimento lentos ascensores cilíndricos, que sobem e descem e se cruzam no espaço, sem vivalma. Há uma ressaca de sons que chega até nós, mas longínqua, confusa, talvez cristais entrechocados, ruídos de facas, de cutelos, ou só uma invisível cascata.

$\mathrm{O}$ ar da madrugada é agora mais seco, a névoa esbranquiçada desapareceu de todo, dir-se-ia que uma luz azul surde do chão, luz mineral, dura, com inesperados reflexos nas abas das cornijas, nas folhas de mármore-cinza dos prédios esqueletos-de-aço, nos terraços-jardins cujas plantas são pólipos, estruturas arborescentes, criaturas de silício. A avenida azul prolonga-se, vasto túmulo deserto, para onde?, entre vidros que cintilam, muros ondulados, torres circulares em cujo ventre os mesmos elevadores morosos prosseguem a sua perturbante, silenciosa marcha contrária. Praia de luz magnética sobre a vegetação química dos geométricos jardins. Água, só esta água de lama, não de medo, na minha boca, dilúvio de lama interior no momento em que o chão se volta.

Não: era apenas uma tontura. Neste bairro de xadrez, cenário de nada, somos nós, perturbados, calados, com os nossos passos vivos, sonoros, a tragédia sem delírio que avança, como? e porquê?

Andamos, cada vez mais depressa. Agora sabemos - mesmo sem o dizermos - que estamos noutra cidade, que passámos, sem dar por isso, da nossa Lisboa ronceira, amodorrada, tranquilamente criminosa e bem pensante, para uma cidade diversa, inominável, sem gente.

- Para onde é que você me trouxe, amigo?

— Eu? - surpreendo-me a responder — também eu posso dizer o mesmo, ora essa!

Todavia, aproximamo-nos um do outro. Sempre somos dois contra o desconhecido, no solo projectado lado a lado em compridas, pálidas sombras. A minha face gelada, imagino-a, sinto-a máscara de proa ao longo dos uniformes edifícios metálicos de laminados lisos e tubos de aço, com blocos-torres, cúpulas, largos vãos envidraçados azul-turquesa, azul-ameixa, azul-violeta; e, por todo o lado, em vez de estátuas, prismas e esferas, mas essas como que movidas pelo frio ar azul, azul sidéreo, o ar-luz que varre a cidade, que nasce ao chão, das estrelas dos mosaicos que piso. 
Entrámos numa vasta praça, de uma geométrica monumentalidade — formas elípticas, fachadas de mármore sobre pilares, temas espaciais de livres diafragmas suspensos. A única decoração, no alto de uma parede nua, cuja pedra tem propriedades idênticas às dos sulfuretos de bário, é um feixe de traços incisos, que assemelha um nervo óptico.

Este portal tão amplo e tão lacónico, de arquitraves majestosas, de um classicismo não arqueológico, será a entrada de um banco, de um ministério, de um hospital modelo?

Há uma força, creio, que para ali nos chama, para aquele pátio de ângulos rectos entrevistos, onde tudo se decompõe. Terá sido o cheiro — primeiro odor desta noite —, vagamente de éter e formol, que me levou a pensar num hospital, com as macas de marfim que lá não estão, ceras petrificadas que afinal não existem no átrio todo liso, mudo? Transpusemos os umbrais; a luz azul, errática, entrou conosco; e, quedos, a meio do átrio, pela primeira vez distinguimos homens e mulheres, dentro dos elevadores que cumprem movimentos inversos, cruzando-se no espaço. Homens com alguma coisa de lagartos, de tão lívidos, a pele como lama branca. Adivinho-os frios, sem voz, figuras quase em estado gasoso.

A mão do professor aperta-me o braço, tanto que me faz doer, mas quando ele abre a boca para falar, fá-lo sem comoção:

- Sabe onde estamos?

Os vagarosos elevadores sobem, descem, segregam um tempo-ausência. As criaturas de lazareto que os ocupam mal se mexem, substância sem reflexos.

São de bronze as minhas pálpebras e dentro do meu crânio há agora sinos, que por fim se desagregam. Sinto então a impossibilidade de mexer os dedos, que ficaram, não sei como, enclavinhados, numa rigidez de pedra. Mas os ascensores não se detêm, no seu matemático vai-vém; só não recordo já desde quando, se de há um instante, de há uma hora, ou de sempre, conheço, reconheço, a sua lívida carga. (RODRIGUES, 1974, p. 555-61)

O conto “Trânsito", de Urbano Tavares Rodrigues, foi publicado em 1966 no livro Imitação da felicidade. Na narrativa, acompanha-se uma deambulação pela cidade de Lisboa que começa a ser descrita após insólita apresentação de balé. O percurso a pé do narradorprotagonista, efetuado inicialmente na Avenida da República e na Avenida de Berna (parte do caminho que se conjectura quando os dois personagens seguem no sentido contrário à Praça de Touros, em direção à Igreja de Fátima), espaço cuja contemporaneidade e referência mimética imediata são reforçadas pela menção a peças publicitárias (Canadian Pacific ou Fanta, por exemplo), cedo se transforma em um passeio insólito por um lugar inexplicavelmente desconhecido e de traços francamente irrealistas, cenário de nada, bairro de xadrez em que o tempo distanciou-se, espécie de não lugar atemporal. Já que, a certa altura, o narrador afirma nunca ter morado em outro sítio que não fosse a capital portuguesa, o que insinua vasto conhecimento do espaço, não há justificativa plausível para que se perdesse. Mas não é mais na Lisboa ronceira, amodorrada, tranquilamente criminosa e bem pensante, com a qual se mostra mais habituado, que agora ele caminha, mas em uma cidade diversa, inominável, sem gente, cidade marcada assim pelo frio ar azul, azul sidéreo, o ar-luz que varre a cidade, por construções de paredes fluorescentes, enfim, pelo odor vagamente de éter e formol: ou seja, um espaço urbano metamorfoseado. Desse modo se exibirá uma cidade que tão depressa se transforma aos olhos do personagem principal do conto e de seus leitores. 
Em sua descrição da capital, o narrador primeiramente faz alusão aos prédios Valmor $^{2}$ - eis a uma Lisboa ronceira e amodorrada, com construções de arquitetura clássica que reproduzem estilos como o gótico ou o renascentista, antiguidade em simulacro para depois descrever espécie de modernismo-futurista em que se usam vidros e estruturas de aço em lugar de alvenaria, modelo longe de encontrar par na Lisboa real da época do conto. ${ }^{3}$ Assim, a estética de cidade fantástica - que essa Lisboa, a princípio mimética, vai adquirindo no decurso da narrativa - aparenta sofrer influência de representações que comumente artistas e cientistas, especialmente a partir do início do século XX, arriscaram usar para predizer o que imaginariam ser uma cidade do futuro. E a partir da metade do conto vislumbramos altas construções luminosas de vidros e de aço ou também uniformes edifícios metálicos de laminados lisos e tubos de aço, com blocos-torres, cúpulas, largos vãos envidraçados azulturquesa, azul-ameixa, azul-violeta - imagens algo fictícias, sobretudo em se tratando de meados da década de 1960 lisboeta, ainda, reiteremos, ronceira e amodorrada, já que prédios de grande altura somente se alastram por Lisboa a partir da década seguinte. Ora, não é a cidade contemporânea à escrita de "Trânsito" que os caminhantes encontram ao fim do percurso. Nesta, se se observa novamente um projeto de engenharia que traz alusão ao passado (como ocorrera com os dos prédios Valmor), o seu resultado não pode ser confundido com uma construção efetivamente remota (e o portal da cena final possui um classicismo não arqueológico). Pode-se citar ainda o que o narrador define conotativamente como uma praia de lu₹ magnética sobre a vegetação química dos geométricos jardins, cena que, se reconhecido o seu cariz futurístico, evidencia uma urbe cujo desenvolvimento se orientara por conhecimentos científicos ligados à física, à química e à matemática, em detrimento de conceitos que se vinculassem às ciências humanas. Reparemos, aliás, que, em direção

\footnotetext{
2 Trata-se de prêmio de arquitetura instituído em 1902 pela Câmara Municipal de Lisboa e que leva o nome do seu idealizador, o segundo Visconde de Valmor. Dentre os vencedores, destaca-se, por exemplo, a Igreja de Fátima, citada no conto.

3 O aspecto atrasado que o narrador destaca na primeira descrição da cidade é fruto de contextos políticos dos anos de 1940 que influenciaram na estética da construção civil de Portugal. Nessa época, o Estado Novo de Salazar rejeitava a construção de prédios modernistas, por considerá-los contrários aos valores nacionais, obrigando diversos projetos a se adequarem a modelos que se inspirassem em palácios do século XVII, nas aldeias portuguesas ou mesmo na arquitetura nazista de feição imperial. Os projetistas, então, passaram a disfarçar os seus desenhos modernistas com excessivas ornamentações que driblassem o olhar censor salazarista, a que foi dado o nome de Estilo Português Suave. Daí as cornijas, conchas, colunatas, capitéis, balaustradas e dentes demasiadamente presentes no conto, a serem classificados depois de ronceirismos pelo narrador. Na época em que se publicou "Trânsito", tais resultados arquitetônicos já eram encarados de modo pejorativo e vastamente criticados pela intelectualidade, a despeito do seu agrado popular. Tais informações são sucintamente descritas no artigo "Lisboa ao longo de uma vida", do arquiteto Nuno Teotónio Pereira.
} 
oposta, o personagem principal possui referências culturais de outra ordem, o que se nota pela menção à apresentação de balé e por sua identificação com o amigo de deambulação, um professor que possui conhecimentos filosóficos, a julgar por suas referências a Sartre e Epicuro. Por isso ele se vê cada vez mais isolado num espaço que valoriza conhecimentos exatos em detrimento a humanos, configurando-se aí uma razão para a sua dificuldade de relação social e a sua sensação de solidão no passeio pelas ruas desertas da urbe noturna. Essas hipotéticas alternativas arquitetônicas futurísticas acompanham modificações conceituais do próprio espaço citadino. À medida que a sociedade pós-industrial cresceu desmesuradamente, a individualidade do cidadão sofreu um processo de controle ou apagamento em prol do funcionamento organizado da coletividade, vista como algo abstrato e não como composição humana heterogênea. Assim, testemunhamos a desconsideração do fator humano por uma cidade que parece progredir em razão de si mesma, ideia corroborada pelas últimas edificações descritas no conto, em que se usam figuras abstratas ao invés de representações do homem: em vez de estátuas, prismas e esferas. A lacuna deixada pela ausência de esculturas que consagrassem formas humanas tende, todavia, a ser ocupada pelo próprio humano em seu processo de reificação: coisificada estará a bailarina com reflexo de bronze, sentada num banco de pedra, cristalizada numa expressão tristíssima; coisificados estarão os dois amigos ao fim do conto, as pálpebras igualmente de bronze, a verificarem a impossibilidade de mexer os dedos enclavinhados, numa rigidez de pedra; coisificados estarão todos tornados estátuas em uma sociedade que, de modo definitivo, os funcionaliza.

Tal conceito de espaço urbano reflete-se na ausência de pessoas nas ruas, motivo pelo qual tudo o que é cabível então apresentar é justamente a geometria das construções, a que o narrador passa a se ater. Suas críticas à cidade se evidenciam nas longas descrições que ele promove dos próprios prédios (não por acaso envolvidos pela névoa fugidia, reforço do seu aspecto negativo), sempre permeadas por adjetivos com valor pejorativo - termos, em maioria, de uso corrente na construção civil e que aqui ganham profícua ambiguidade: tortos cordões de pedra, pifias estilizações, capitéis chorudos, dentes inchados, arremedos de feras hiantes, balaustradas gordas, obesos adornos assimétricos, ferros forjados. A observância dessa metamorfose, que, em "Trânsito", repentinamente se processa diante dos olhos do narrador em uma velocidade maior do que a sua faculdade para acompanhá-la (reiteremos sua queixa de que tão depressa a cidade se transforma) leva à gradativa instauração de um ambiente fantástico, de modo que o ponto final da jornada dos personagens se contrapõe 
àquela cidade de relação aparentemente mais fotográfica com a Lisboa real descrita no princípio. Mas já desde o começo o frio do inverno e o nevoeiro não são capazes de verdadeiramente explicar esse aspecto estranhamente calmo (mesmo para o período noturno) de um dos principais eixos da ligação entre o Norte e o Sul de Lisboa promovida pelas chamadas Avenidas Novas, nas quais não se cruza com pessoa alguma, exceção feita ao professor Benavente. Acresce-se a isso a cena do balé, que já faz com que o leitor seja absorvido por uma atmosfera insólita desde as linhas iniciais do conto.

Fosse porque o espetáculo ocorresse em um espaço não convencional e aberto ao invés de um teatro com o seu palco convencional, fosse porque se tratasse de uma apresentação de viés talvez mais brechtiano (as descrições não permitem uma conclusão precisa, o que potencializa a atmosfera de estranhamento), a bailarina interage continuamente com o narrador até, a certa altura, ser conduzida para fora do círculo iluminado em que dança para que ele se arrisque a dizer-lhe o nome, a vagamente reconhecê-la: Rosa, Luisa, Júlia... As respostas que a chorosa dançarina lhe dá a cada tentativa (Não o conbeço...; Ou já o esqueci... Ninguém se conbece, não é verdade?; Não vale a pena. Não te esforces...) são indícios de um dos motes da narrativa, a inépcia do homem moderno em relacionar-se plenamente e em reconhecer-se a si e aos outros. $\mathrm{O}$ narrador classifica essa apresentação artística como um divertissement, ato de uma peça de balé que não estabelece relação direta com o desenvolvimento do seu enredo. Poderia ser esse o modo proposto de entender a coesão entre a introdução da narrativa e o restante do conto, a julgar especialmente pela forma inesperada e aparentemente desconexa com que se transita de um movimento para o outro, como se sucedesse a justaposição de textos distintos e passássemos subitamente a ler uma nova narrativa que se inicia e, a princípio, referenciaria pouco ou nada da anterior. $\mathrm{Na}$ verdade, essa cena do balé tem pouco a ver com a descrição mimética de um espectador que vai ao teatro, funcionando muito mais como delírio do personagem, impossibilidade de atribuição de limites entre a ficção (dança) e a realidade. Pois o narrador do conto, por assim dizer, dançará um balé semelhante durante o transcorrer do conto, tanto que o passo final executado por ele e por seu par será precisamente a imobilização, numa rigidez de pedra, ambos também quedos e a meio do átrio, sob uma luz ąul, errática - isto é, posição física e localização espacial comparáveis às que se encontram as bailarinas ao fim do espetáculo, que antes se movimentaram de forma análoga ao estacarem no círculo iluminado. O divertissement da abertura do conto autentica-se, 
desse modo, como reprodução metonímica do deslocamento pela cidade a ser concretizado adiante.

Consta da cenografia do espetáculo a tapeçaria de cor indefinida, entre o rosa e o amarelo, como deve ser o cetim dos ventres interiores, além dos espelhos, cuja quantidade o narrador não pode precisar: Espelhos há quatro. Ou cinco? Se assim é, do mesmo modo será passível de dúvida a contabilidade supostamente precisa que se exibe no parágrafo seguinte: São cinco bailarinas brancas. Afinal, poderiam elas ser, de igual modo, apenas quatro (ou até menos) e a presença dos espelhos teria confundido o narrador, já que muito convenientemente tratava-se de rapariguinhas de branco, quase gêmeas. Quiçá será a imagem alegórica desses espelhos o que permitirá que a segunda parte do conto seja então essa espécie de reflexo do divertissement que o inicia. Quiçá sejam esses os espelhos que o narrador então metaforicamente atravessa, como a Alice de Lewis Carrol, a fim de partir de uma cidade similar àquela em que vive para, a seguir, chegar a ela mesma transformada em outra. A impossibilidade de identificar as pessoas (a falta de habilidade de o narrador nomear corretamente a bailarina), bem como a relação geminal que se estabelece entre essa dançarina e as suas colegas de coreografia, que podem funcionar tão somente como duplicações suas, permitidas pela existência real ou metafórica dos vários espelhos, não podem assim evitar a solidão. Por isso, ela chora e passa por um conjunto de pequenas metamorfoses enquanto conversa com o protagonista, sentada em um banco que fica, a propósito, encostado aos espelhos, como a pele que clareia e o olhar que esverdeia, comprometendo ainda mais sua identidade. Isso alegoriza essa cidade deserta ${ }^{4}$ pela qual o narrador caminhará mais adiante, espaço citadino onde, normalmente, as pessoas não se podem distinguir e as relações humanas se tornam, por essa razão, improváveis. A sensação de se estar só em meio à multidão, forçoso estado citadino, irá revelar-se então a principal questão dramática de "Trânsito".

Como em relação à bailarina em sua convivência com as colegas gêmeas, também no caso do protagonista a repentina presença de Benavente para acompanhá-lo não será verdadeiramente capaz de rescindir essa solidão, uma vez que a aparição do companheiro é envolta de certa ambiguidade, como se não acontecesse literalmente e, nesse sentido, favorecendo o fato de não provocar espanto; como uma estratégia do narrador para

\footnotetext{
${ }^{4}$ Outra leitura possível para o conto seria a que dá conta nos anos de 1960 do trânsito ilegal de portugueses que, em busca de melhores condições de vida, migraram para a França. Especula-se que cerca de um milhão de pessoas deixaram o país na época, sem contar os mais de um milhão e meio de portugueses que já viviam em Angola ou Moçambique, o que, para uma população que, segundo censos (superestimados já que mascarados pela ditadura salazarista para forjar processos eleitorais) não chegava a nove milhões, representa significativo esvaziamento, uma desertificação do país.
} 
conversar consigo mesmo, através de uma segunda voz representada por aquele que ocuparia para ele um lugar de mentor, como, aliás, até sugere o título de professor. Através desse processo dialógico (em um estilo que lembra recursos retóricos clássicos usados por Platão e Aristóteles), o personagem será capaz de desenvolver breves discussões epistemológicas, dentre as quais a que faz menção a teses defendidas por Sartre, citadas quando o professor exibe as fundamentações do existencialista exibidas em um dos seus primeiros escritos publicados, em 1936: A imaginação. Sem pretender uma investigação mais profunda dessa teoria, limitemo-nos a buscar o que parece ser fundamental à interpretação do conto: a diferença que Sartre estabelece entre duas formas possíveis de existência uma como coisa e outra como imagem. Para demonstrar tal ideia, o ensaísta usa o exemplo de uma folha de papel em branco que se encontrasse em sua escrivaninha: ao olhar para ela, afirma estabelecer contato com a sua existência como coisa, que não está sujeita à sua constatação, não depende de nenbuma espontaneidade nem de uma consciência; mas, ao voltar o rosto para a parede, alega ainda poder visualizar essa folha que continua todavia sobre a mesa, instituindo dessa forma a sua existência como imagem, a qual, por sua vez, depende da reflexão de uma consciência e possui com a folha-coisa uma identidade de essência. Sartre, porém, reconhece que essas duas existências podem ser facilmente confundidas pelo homem e cremos que essa possibilidade de conflito é o que se mostra mais fértil para a interpretação desse conto. Discursa, deste modo, o filósofo:

[...] essa confusão dos modos de ser é tentadora, pois afinal a folha em imagem e a folha em realidade são uma única e mesma folha em dois planos diferentes de existência. Por conseguinte, tão logo o espírito se desvia da pura contemplação da imagem enquanto tal, tão logo se pensa sobre a imagem sem formar imagens, produz-se um deslizamento e se passa, da afirmação da identidade de essência entre imagem e objeto, à de uma identidade de existência. Já que a imagem é o objeto, conclui-se que a imagem existe como o objeto. E, dessa maneira, constitui-se o que chamaremos a metafísica ingênua da imagem. Essa metafísica consiste em fazer da imagem uma cópia da coisa, existindo ela própria como uma coisa. Eis aí, portanto, a folha de papel “em imagem” provida das mesmas qualidades que a folha de papel "em pessoa". Ela é inerte, não existe mais apenas para a consciência: existe em si, aparece e desaparece a seu critério e não ao critério da consciência; não cessa de existir ao deixar de ser percebida, mas continua tendo, fora da consciência, uma existência de coisa. Essa metafísica, ou melhor, essa ontologia ingênua é a de todo mundo. Por isso, observamos o curioso paradoxo: [...] acaba por [se] constituir, em vez de uma única folha de papel em dois planos de existência, duas folhas rigorosamente semelhantes que existem no mesmo plano. (SARTRE, 2010, p. 9-10)

A imagem, ao contrário do objeto, depende da subjetividade de uma determinada consciência para que seus traços possam ser definidos. Ora, a Lisboa descrita pelo narrador em "Trânsito", mesmo em momentos de maior mimetismo, não representa na verdade a 
sua existência como coisa, mas como imagem, aquela que o autor será capaz de atribuir à cidade em razão de suas visões particulares sobre ela, até porque é feita de linguagem: a isso equivale, aliás, qualquer produção artístico-literária. Trata-se, assim, de uma cidade que, como a folha de papel sartriana, "não existe de fato, ela existe em imagem" (SARTRE, 2010, p. 8). Tomando, todavia, uma perspectiva interna da narrativa, fincando bases na argumentação que o protagonista seria capaz de, interdiegeticamente, elaborar, percebemos que esse espaço urbano inicial, o da Lisboa amodorrada e ronceira, identificar-se-ia com uma existência como coisa para o personagem e aquela alcançada mais tarde com uma existência como imagem. Mas $\mathrm{O}$ narrador, vitimado por sua metafísica ingênua da imagem (seu delírio? seu sonho?), não compreende que, ao ultrapassar o espelho, alcança outro plano de existência e deambula assim na cidade-imagem que criara cuidando que estivesse na cidade-coisa. E as características da cidade-coisa é que provocam essa percepção particular do espaço urbano que o narrador descreve (daí a importância de que compareça na primeira pessoa verbal). Assim, o espaço-imagem é apresentado sob um discurso de estranhamento porque tão depressa a cidade [coisa] se transforma [em imagem] (e a noite tudo confunde) que por consequência o herói não é mais capaz de associá-la à Lisboa-coisa de sua memória. Assim também a incomum luz azul que irá matizar a urbe-imagem tão somente simboliza uma urbe-coisa que ele não pode mais descodificar e que por isso ganha essa tonalização insueta. Assim, finalmente, o esvaziamento que se percebe nas ruas-imagem é fruto de uma percepção de isolamento do homem nas ruas-coisa — ideia simbolizada na metáfora dos elevadores: os homens se cruzam na multidão sem em momento algum se encontrarem.

Pensemos pois nessa última imagem. Não é difícil encontrar em tais homens que se transportam no espaço através de elevadores isolados dos demais uma metáfora também para o trânsito realizado em automóveis, nos quais milhares de pessoas cruzam uma cidade sem interagir com as demais. Ora, no espaço urbano descrito nesse conto intitulado exatamente "Trânsito", a ausência da multidão indicia essa transferência do protagonismo urbano do homem aos elementos inanimados: notadamente aos prédios, mas também aos automóveis. A descrição de um edifício garagem metaforiza, assim, com maior precisão, a cidade que reconhecemos existir em função de si própria, promovendo a inversão de valores entre meios e fins: a construção configura-se em um imenso stand de automóveis verdes, beges, cinzentos, piscineos, cromados, alinhados em placa de cristal - o edifício, todo em planos horizontais e com painéis de polyester translúcido. Há, então, evidente teor de ironia para o título da obra, já que, na verdade, a cidade parece imóvel (os carros estão guardados nos prédios) 
e o único - e mesmo último - trânsito que ainda haveria até o termo da narrativa seria o do narrador e de seu companheiro de caminhada, que, aliás, são chegados às luzes intermitentes da sinalização, criadas todavia em função da existência dos veículos. E quando automóveis estão abrigados pelo edifício enquanto duas pessoas andam nas ruas sob o controle dos semáforos, promove-se uma clara inversão de papéis, em que se evidencia novamente a reificação do homem e a consequente subjetivação das coisas.

Mas outro sentido possui o esvaziamento da cidade: ora, se "o tema urbano por excelência são 'as massas"' (BOLLE, 2000, 78), segundo sagrara Willie Bolle, não é admissível estabelecer conhecimento sobre um espaço urbano esvaziado porque é como se ele também não existisse, não acontecesse, não se concretizasse, restando apenas a falta de entendimento a seu respeito. É então porque se encontra sem gente que a cidade se torna inominável, conforme constatamos textualmente (inominável como são as bailarinas e mesmo o protagonista). O único equacionamento viável para esta incógnita que se tornara o espaço urbano, cuja leitura é recusada, será a absoluta incompreensão ao seu respeito, o que culmina, simbolicamente, nas descrições cada vez mais insólitas e ilógicas sobre a cidade. A cidade vazia de "Trânsito" é precisamente aquela que não se pode racionalizar. A incapacidade de compreender o espaço urbano talvez fosse um dos sentidos possíveis para a expressão substâncias sem reflexo, que define os homens e mulheres que transitam por intermédio dos elevadores. É necessário, para isso, pensar na ambiguidade do termo reflexo, que se referiria não apenas à reprodução da imagem, quando significaria então exatamente a solidão desses seres, que não encontram par na cidade moderna, todavia podendo a expressão estar relacionada ao campo semântico do pensamento: essas pessoas sem reflexo perderam, na realidade, a capacidade de leitura do mundo, isolados que estão em suas cápsulas de transporte, sejam efetivamente os elevadores, sejam os automóveis que eles simbolizariam, seja a barreira de defesa que esses habitantes da urbe moderna normalmente criam contra as suas ameaças e que impede as suas interações com outras pessoas nas ruas. Essa substância sem reflexo, porém, pode fazer menção ainda (e retomamos então o sentido que originalmente lhe tínhamos atribuído) a uma literal ausência de espelhos, objetos sem os quais não pode mesmo haver reflexão de imagem e que povoaram a cena inicial transformando-se nessa espécie de caminho de Alice que levou o protagonista a um espaço de representação urbana que a sua percepção intuiu. Não haver espelho que ofereça essa mesma propriedade de portal entre dois mundos (ou, nesse caso, para manter o conceito fornecido pela teoria sartriana, entre dois planos de existência, a como coisa e a como 
imagem) sugere a impossibilidade de se localizar um caminho de volta semelhante ao de ida e, portanto, a irreversibilidade do percurso empreendido pelo herói. Ora, tal dado somado ao fato de que, no trajeto, conforme já ressaltamos, as construções descritas parecem encaminhar o leitor para uma cidade de aspecto futurístico — permite crer que esse percurso seria regido por uma representação da passagem do tempo, afinal, trata-se de uma viagem sem retorno, propriedade pertinente a essa grandeza.

Não defendemos um teor efetivamente futurista para "Trânsito", que se passa antes em uma contemporaneidade a qual, no entanto, o protagonista, com um olhar ainda habituado a certo passado, não consegue mais distinguir, de tal modo que isso lhe sobrevém com as marcas do fantástico. A despeito das descrições finais do texto, é preciso pesar uma vez mais o fato de que se lida aqui com um narrador-personagem: e essa opção se mostra, na verdade, um sofisticado recurso para expor não a visão de um personagem que encara uma cidade supostamente futura, mas o olhar de alguém que não entenderia mais a sua cidade atual, ainda que ela não tivesse alcançado efetivamente aquela arquitetura. Não é pois a cidade que é futurista mas o herói é que é anacrônico. A cidade espanta porque é metaforicamente futurista e esse futuro é tão somente a projeção do espanto do protagonista que não a consegue ler, já que é através dos seus olhos que a vemos. É assim que se sinaliza um personagem tornado arbitrariamente anacrônico, no sentido de que seus modos característicos de interpretar o mundo não se aplicam mais ao tempo presente como quiçá eram funcionais em momentos pretéritos. "Trânsito" é então menos uma narrativa que trata somente da metamorfose urbana (da observável à conjecturada) do que um conto que, especialmente, tematiza a tragédia do seu personagem central. Ora, dizer que essa cidade se altera em razão de uma passagem pelo espelho foi justamente entender que é para a sua subjetividade que o herói se encaminha, para a cidade que ele particularmente enxerga. Por isso há no decorrer do texto tantas referências ao interior do corpo, como ventres, diafragmas e nervos ópticos (mesmo a imagem dos elevadores luminosos a cruzarem-se remeteriam a representações das sinapses cerebrais entre os neurônios). É por dentro de si que o protagonista envereda — também é a sua imagem que reflete nesse espelho - e é, por conseguinte, para dentro de si que ele se volta. Tal conclusão é, aliás, basilar para que finalmente se compreenda a figura do seu companheiro de deambulação: afinal, ele vai ao encontro de si mesmo e, no entanto, depara-se, sem se surpreender, com o professor Benavente. 
Por isso é que a presença do professor não poderia atenuar a solidão do protagonista. $\mathrm{Na}$ qualidade de seu antigo mentor, Benavente já não pareceria presente de fato, funcionando tão somente como um seu alter ego. O professor, que a propósito será o único personagem nomeado no conto, é assim somente uma duplicação da própria consciência do protagonista, sendo, a exemplo das bailarinas, sua reprodução geminal, seu duplo. Tal identificação justifica que o professor falasse comigo-consigo. Assim, a metáfora das sombras (Sempre somos dois contra o desconhecido, no solo projectados lado a lado em compridas, pálidas sombras.) se torna importante porque a aproximação de ambos tem como resultado evidente suas projeções como uma imagem, sombras contra o desconhecido, valor único contrário a tudo o que lhes é alteridade, momento em que a fronteira entre as até então supostas individualidades de dois seres ganha certa continuidade funcional sugestiva do lugar similar que ocupam. Encarar os dois personagens como um único explica o porquê de a dupla de verbos conheço / reconheço surgir duas vezes no texto, sempre em sequência, ambas em posição de destaque, no início e no encerramento do conto (o narrador afirma que conhece e reconhece o divertissement a que assiste, assim como conhece e reconbece a livida carga dos ascensores enquanto está petrificado na cena final). É preciso ser dois para primeiro realizar uma das ações e depois, de imediato, repeti-la: assim, aquilo que o Benavente de dez anos atrás conhece o Benavente atual re-conhece. Mas antes de perceber no companheiro de caminhada a reprodução do próprio narrador seria preciso ponderar sobre o único bailarino que se apresenta junto às moças, o qual é possível supor que desempenhe uma função semelhante à do professor — outra duplicação especular do protagonista. Vale ressaltar, todavia, que é sempre de costas para o narrador que ele surge, e, sendo assim, pela presença dos espelhos em cena, mostrar-se-ia admissível que, numa associação livre de ideias, justapuséssemos essa imagem à tela de René Magritte de 1937 batizada $A$ reprodução interdita, famosa pintura surrealista em que um homem, de espaldas para o espectador, observa no espelho à sua frente o seu reflexo, onde no entanto ele também surge de costas - efeito impossível no mundo empírico. É efetivamente como outro que ele mesmo se vê ao espelho (tal qual é também como outro que o narrador tratará o professor que é ele mesmo). Se imaginássemos que diante do homem espelhado da tela do pintor belga houvesse novo espelho, a figura seria reproduzida, em mise en abyme, indefinidamente; ou, antes, até que não mais restassem espelhos, ausência aliás que já constatamos ocorrer na segunda parte do conto, o que então interromperia a jornada. E, caso fosse a vida do herói que esse percurso de várias imagens segmentadas metaforizasse, a ausência de um novo espelho que ainda 
permitisse a continuidade da estrutura de abismo criada significaria, portanto, a interrupção do caminho, o fundo desse mesmo precipício em que caíra, (e eis a sua petrificação, configurada na impossibilidade de seguir a sua deambulação), detença que significaria então, em termos denotativos, a sua morte.

E é indubitavelmente para a morte que o protagonista se orienta: destino inevitável desse itinerário irreversível que é o tempo-vida cuja única opção é a interrupção, o pararmorrer (ou, como se vê textualmente, petrificar-se). Talvez por isso ele creia que a última construção encontrada em sua deambulação seja um hospital (chega a atribuir tal intuição ao cheiro vagamente de éter e de formol. Nesse sentido, seria a cena primeira, a do balé, o marco inicial dessa jornada que fora a vida de Benavente (e podemos a essa altura assim nos referir ao personagem que narra o conto). $\mathrm{Na}$ linha de leitura proposta, então, por esse motivo é que se faria a referência ao ventre quando se descreve a tapeçaria que serve de fundo ao cenário do espetáculo. O pano, aliás, possui características marinhas: o protagonista afirma ter nas mãos uma renda de sal; há espumas, e há ondas, e areias sujas e conchas nesta tapeçaria que os espelhos multiplicam, o que reforça assim a metáfora, porque não apenas o mar é reconhecido pelas ciências biológicas como o berço da vida na terra como também é imerso em água que todo ser humano se desenvolve em sua fase uterina, além, é claro, de haver num complemento da simbologia esse poder multiplicador dos espelhos, igualmente ligado ao campo semântico de reprodução da espécie. Talvez em função desse seu sentido, a primeira parte do conto seja sonorizada de modo aparentemente abafado: A música mal se ouve, interrompida; é luz decapitada, longe. — como se pode imaginar que sejam os sons que chegam a um feto no útero. Daí, portanto, que se passe da cena do balé para a da deambulação de modo abrupto, tão somente através do período: Terminou a festa, suponbo, e a rua está fria. A festa que terminou é a vida de Benavente, de que a narrativa não fornece nenhuma informação porque a omite nessa elipse (a grande velocidade da queda no abyme), descrevendo alegoricamente apenas os seus dois extremos, marcos inicial e final: gestação e morte. O inverno, estação que fecha um circuito iniciado pela primavera (comumente associada ao nascimento) é símbolo recorrente para a morte que nesse conto comparece. Também o fará, além disso, a noite durante a qual Benavente caminha, que igualmente se estabelece como um fim de ciclo. E o quase ininterrupto silêncio da cidade possui semelhante riqueza simbólica. E, logo, a cruz da Igreja de Fátima pelo mesmo motivo teria sido enfatizada durante a deambulação, como último ponto de referência a que a dupla caminhante pôde aludir da Lisboa mimética, a Lisboa-coisa que ficara para trás. 
Evidentemente, seria possível presumir ainda a causa mortis do personagem, afinal, trata-se de uma narrativa intitulada "Trânsito" - que pode ambiguamente fazer referência a essa transição que o personagem faz da cidade-coisa para a cidade-imagem, ou a que o encaminharia da vida para a morte. Mais do que isso, trânsito poderia identificar a ocorrência que o vitimara, especialmente se pensarmos que a transformação da cidade testemunhada pelo herói caminhante começa a se processar mais ou menos a partir do momento em que atravessa, diante do semáforo, a Avenida da República. Nesse sentido, outra vertente de leitura levaria a crer que toda a narrativa descrevesse um delírio que o personagem sofre em razão de uma circunstância de agonia, momentos finais de vida cuja expiração fosse catalisada por um atropelamento. Tal opção, por outro lado, persuadiria a encarar o pano cor de ventre da cena inicial como o próprio abdômen aberto do personagem, a agonizar em uma sala de operação (e as menções a signos hospitalares na parte final do texto de outra maneira, por conseguinte, se justificariam). E, finalmente, as várias mulheres inominadas que com ele cruzam no balé inicial configurariam projeções das frágeis e fugazes relações amorosas que ele estabelecera no decorrer da vida e pelas quais lamenta em seu segundo fatal, em uma tentativa desesperada de corrigir o que não possui mais tempo para refazer, de agregar-se aos seus amores e às suas paixões quando não mais os há: resulta disso o seu empenho para lembrar o nome da bailarina, que ela mesma diagnostica como vão (Não vale a pena. Não te esforces). Assim, a visão do espetáculo de balé torna-se um desfile de mulheres com quem ele se relacionou na vida, das quais, no entanto, não guarda lembrança precisa, mas que lhe reapareciam em espécie de retrospectiva por ocasião de sua morte, configurando algo como um delírio moribundo.

Mas outra morte, no plano simbólico, essa morte efetiva do protagonista representa: a do homem capaz de ler a cidade em que circula, cuja consequência é a potencialização do aspecto insólito da Lisboa do conto, a tornar interdita a reflexão de uma cidade que assim se tornara também interdita à reflexão.

\section{BIBLIOGRAFIA}

BOLLE, Willi. 2000. Fisiognomia da metrópole moderna. São Paulo: EDUSP.

PEREIRA, Nuno Teotónio. 1999. "Lisboa ao longo de uma vida". In: Revista Semear. Rio de Janeiro: Ed. Puc-Rio, nº3, p. 9-21.

RODRIGUES, Urbano Tavares. 1974. "Trânsito". In: CASTRO, E. M. de Melo e (org.). Antologia do conto fantástico português. Lisboa: Edições Afrodite, p. 553-61.

SARTRE, Jean Paul. 2010. A Imaginação. Trad. Paulo Neves. Porto Alegre: L\&PM. 
Revista $\because$

Artigo recebido em 26 de Agosto de 2012.

Artigo aprovado em 11 de Novembro de 2012. 